Introduction

\title{
Capitalism: Theological Perspectives and Critiques
}

\author{
Neil Messer
}

The essays published in this issue have their origins in the 'Futures of Capitalism' project sponsored by the University of Winchester, Winchester Cathedral and Winchester Business Improvement District, in collaboration with the McDonald Centre for Theology, Ethics and Public Life, University of Oxford. Conceived in the wake of the 2008 global economic crisis and the 'Occupy' protests around the world, the project was an attempt to make positive contributions to debates about the reform and renewal of the economy. It included artistic, cultural and educational events, as well as a short academic conference held at the University of Winchester in April 2014. Three of the four papers that follow were presented at the conference, while the other, unavailable for presentation at the time, was subsequently commissioned for the present issue. These four papers represent varied and contrasting possibilities for critical and constructive engagement by religious - particularly Christian - traditions with twenty-first century capitalism.

In different ways, the first two papers focus on the Hebrew Bible (Old Testament) and bring it into engagement with twenty-first century capitalist economies. The Old Testament scholar Walter Houston offers a detailed study of the Hebrew term mishpat utsedaqa ('justice and righteousness'), widely used in the Hebrew Bible in the context of what would now be called social and economic ethics. The use of this term in the biblical texts, he argues, indicates an assumption that the state (in the person of the monarch) had a duty to exercise power so as to protect the poor and vulnerable. Despite the broad gap between biblical and twenty-first century contexts, Houston holds that a Gadamerian 'merging of the horizons' can enable these texts to inform present-day ethical reflections on social and economic ethics. He concludes with some sharply critical reflections on the extent to which contemporary governments - particularly in Britain and the USA - are fulfilling the responsibilities disclosed by such reflection.

Kevin Hargaden's essay takes as its starting point the part that a dysfunctional property market played in the Irish economic crash of 2008. Such a market, he holds, was in effect usurious, and is called into question by the strictures against usury found in the Hebrew Bible and much of the Christian tradition. He argues, moreover, that even functional rental markets have ethical problems when considered in Christian perspective. Informed by an analogical reading of the 'Song of the Vineyard' in chapter 5 of the book of Isaiah, the paper concludes with a call for Christians and churches to engage in forms of 'experimentation' with ways of meeting people's housing needs that are not directed to the goal of profit. 
Jeremy Kidwell's paper turns our attention away from the post-2008 global financial crisis to the less familiar story of the 2010 'Flash Crash', in which major stock markets crashed severely and then recovered, within around half an hour on a single day. This sudden and unexpected market volatility has been attributed to the loss of human control when extraordinarily high-speed stock market trading is done by means of computer algorithms. For Kidwell, this is just one instance of the problematic relationship contemporary business has with time. By way of Giorgio Agamben's account of 'messianic time', he argues that a theological understanding of temporality can suggest more sustainable ways in which businesses may relate to their past and future and inhabit the present.

The final paper, by Peter Heslam, takes a sociological turn. Acknowledging Max Weber's classic analysis linking Protestantism with the rise of capitalism, he argues that the growth of entrepreneurial capitalism in the global South is similarly associated with the growth of evangelical, Pentecostal and charismatic Christian churches. In particular he singles out three features of this Christian movement: self-empowerment (especially of women), church-based charitable and social initiatives, and the growth of trust. These, he argues, can supply the social, moral and spiritual capital to support forms of development that serve the common good.

These four papers, of course, represent only a small sample of the many ways in which Christian traditions can engage with the ethical questions thrown up by the postcrash global economy. Even among the voices represented here, there will be diverse conversations, some enthusiastic agreements and some vigorous disputes. This selection therefore serves to illustrate the potential in Christian ethical traditions for fruitful and provocative reflection on these matters of vital current concern.

I am grateful to all who have contributed in various ways to the genesis of this issue: those involved in the 'Futures of Capitalism' project and particularly Canon Roland Riem for his role in initiating it; all the speakers and participants in the conference which generated these papers; the authors for the quality of their contributions and their willingness to work within sometimes tight editorial schedules; the anonymous peerreviewers for their careful and helpful work; and finally the editorial team of De Ethica, particularly Marcus Agnafors, for wise guidance and considerable patience.

Neil Messer, University of Winchester neil.messer@winchester.ac.uk 